\title{
Heart failure compromises muscle power of lower limbs of sedentary elderly people
}

Insuficiência cardíaca compromete potência muscular dos membros inferiores de idosos sedentários

Insuficiencia cardíaca compromete potencia muscular de extremidades inferiores de los ancianos sedentarios

Roberto Cascon

ORCID: https://orcid.org/0000-0002-6957-7524 ACE Exercise Cardiology, Brazil E-mail: robertocascon@cardiologiadoexercicio.com.br

Amanda Brown

ORCID: https://orcid.org/0000-0001-7971-330X Federal Institute of Sudeste of Minas Gerais, Brazil

E-mail: amanda.brown@ifsudestemg.edu.br

Diogo Cardozo

ORCID: https://orcid.org/0000-0001-9725-4952 Federal University of Rio de Janeiro, Brazil E-mail: dcardozoef@gmail.com

Marcelo Corso

ORCID: https://orcid.org/0000-0003-0054-3964

Federal University of Rio de Janeiro, Brazil

E-mail: profmarcelocorso@gmail.com

Leandro de Oliveira Sant'Ana

ORCID: https://orcid.org/0000-0002-0156-4030

Federal University of Juiz de Fora, Brazil E-mail: losantana.ufjf@gmail.com

Mauro Augusto dos Santos

ORCID: https://orcid.org/0000-0001-9515-0594 ACE Exercise Cardiology, Brazil

E-mail: mauroaugusto@cardiologiadoexercicio.com.br Ingrid Dias

ORCID: https://orcid.org/0000-0001-7682-3992

Federal University of Rio de Janeiro, Brazil E-mail: ingriddias.ufrj@gmail.com

Alex Souto Maior

ORCID: https://orcid.org/0000-0002-3005-0135 Augusto Motta University Center, Brazil E-mail: alex.bioengenharia@gmail.com

Verônica Salerno

ORCID: https://orcid.org/0000-0002-4344-6710 Federal University of Rio de Janeiro, Brazil E-mail: vpsalerno@yahoo.com.br

Jeffrey M. Willardson

ORCID: https://orcid.org/0000-0002-7428-3408 Rocky Mountain College, USA E-mail: jeffrey.willardson@ rocky.edu

Roberto Simão

ORCID: https://orcid.org/0000-0002-3725-3437 Federal University of Rio de Janeiro, Brazil E-mail: simao@phorte.com.br

\begin{abstract}
Purpose. To analyze and to compare the absolute and relative muscle power of the lower limbs in sedentary elderly subjects with and without heart failure. Methods. The study included 36 elderly subjects $(72 \pm 6.5$ years, $76.8 \pm 4.8$ $\mathrm{kg}, 171 \pm 9.4 \mathrm{~cm}$ ) divided into two groups: sixteen patients with heart failure versus twenty patients with coronary artery disease, but without heart failure. The muscle power of the lower limbs was assessed with a half-squat exercise; three repetitions were performed with three seconds of the interval between repetitions as fast as possible in the concentric phase. For the statistical analysis, unpaired Student's t-tests were used to compare the absolute and relative muscular power between groups. Results. Subjects without heart failure had significantly greater absolute (362 \pm 18.5
\end{abstract}


$\mathrm{W}$ vs. $438 \pm 22.3 \mathrm{~W}, \mathrm{p}=0.015)$ and relative $(4.6 \pm 0.2 \mathrm{~W} / \mathrm{kg}$ vs. $5.9 \pm 0.2 \mathrm{~W} / \mathrm{Kg}, \mathrm{p}=0.001)$ muscle power versus subjects with heart failure. Conclusion. Heart failure harms the muscular power of the lower limbs in the elderly, which may influence the prognosis and evolution of the disease and capacity functional.

Keywords: Heart failure; Elderly; Muscle strength.

\begin{abstract}
Resumo
Objetivo. Analisar e comparar a potência muscular absoluta e relativa dos membros inferiores em idosos sedentários com e sem insuficiência cardíaca. Métodos. O estudo incluiu 36 idosos $(72 \pm 6,5$ anos, 76,8 $\pm 4,8 \mathrm{~kg}, 171 \pm 9,4 \mathrm{~cm})$ divididos em dois grupos: dezesseis pacientes com insuficiência cardíaca versus vinte pacientes com doença arterial coronariana, mas sem insuficiência cardíaca. A potência muscular dos membros inferiores foi avaliada com um exercício de meio agachamento através de três repetições executadas com três segundos de intervalo entre elas e com a máxima velocidade na fase concêntrica. Para análise estatística, os testes t Student's não pareados foi usado para comparar a potência muscular absoluta e relativa entre os grupos. Resultados. Indivíduos sem insuficiência cardíaca tiveram significativamente maior potência muscular absoluta $(362 \pm 18,5 \mathrm{~W}$ vs. $438 \pm 22,3 \mathrm{~W}, \mathrm{p}=0,015)$ e relativa $(4,6 \pm 0,2 \mathrm{~W} / \mathrm{kg}$ vs. $5,9 \pm 0,2 \mathrm{~W} / \mathrm{Kg}, \mathrm{p}=0,001)$ comparados com os indivíduos com insuficiência cardíaca. Conclusão. A insuficiência cardíaca prejudica a potência muscular dos membros inferiores em idosos, o que pode influenciar no prognóstico e na evolução da doença e na capacidade funcional.
\end{abstract}

Palavras-chave: Insuficiência cardíaca; Idoso; Força muscular.

\title{
Resumen
}

Objetivo. Analizar y comparar la potencia muscular absoluta y relativa de los miembros inferiores en ancianos sedentarios con y sin insuficiencia cardíaca. Métodos. El estudio incluyó a 36 ancianos (72 \pm 6,5 años, 76,8 \pm 4,8 kg, $171 \pm 9,4 \mathrm{~cm}$ ) divididos en dos grupos: dieciséis pacientes con insuficiencia cardíaca versus veinte pacientes con enfermedad de las arterias coronarias pero sin insuficiencia cardíaca parada cardíaca. A potência muscular dos membros inferiores foi avaliada com um exercício de meio agachamento através de três repetições executadas com três segundos de intervalo entre elas e com a máxima velocidade na fase concêntrica. La potencia muscular relativa y absoluta de las extremidades inferiores se evaluó con un ejercicio de media sentadilla. Para el análisis estadístico, se utilizaron pruebas t de Student para datos no apareados para comparar la potencia muscular absoluta y relativa entre grupos. Resultados. Los individuos sin insuficiencia cardíaca tenían una potencia muscular absoluta significativamente mayor $(362 \pm 18,5 \mathrm{~W}$ frente a $438 \pm 22,3 \mathrm{~W}, \mathrm{p}=0,015)$ y relativa $(4,6 \pm 0,2 \mathrm{~W} / \mathrm{kg}$ frente a $5,9 \pm$ $0,2 \mathrm{~W} / \mathrm{kg}, \mathrm{p}=0,001)$ en comparación con las personas con insuficiencia cardíaca. Conclusión. La insuficiencia cardíaca deteriora la potencia muscular de los miembros inferiores en el anciano, lo que puede influir en el pronóstico y evolución de la enfermedad y la capacidad funcional.

Palabras clave: Insuficiencia cardíaca; Anciano; Fuerza muscular.

\section{Introduction}

Cardiovascular disease (CVD) is the leading worldwide cause of premature death (Naghavi et al. 2016), being the practice of strength training (ST) one important strategy for prevention and rehabilitation in this population (Drenowatz et al. 2015, Price et al. 2016, Shiroma et al. 2017; Xanthos et al. 2017; Hansen et al. 2019; Singh et al. 2019). Another group that may benefit from this type of exercise is elderly by increasing the muscle function, mainly through muscle power (MP) exercises (Fragala et al. 2019). However, the evidence concerning the ST for this purpose by the elderly with heart failure (HF) and coronary artery disease (CAD) need more explanation.

HF and CAD are common diseases with age (Dharmarajan et al. 2017) characterized by structural or functional impairment of ventricular filling or blood ejection (Yancy et al. 2013) and an atherosclerotic occlusion that results in functional alterations of coronary arteries (European Society of Cardiology, 2013), respectively. Both imply hemodynamic and neuroendocrine adaptations, such as parasympathetic withdrawal, impaired regulation of the renin-angiotensin-aldosterone system, and inflammatory status (Malakar et al. 2019). These changes contribute to sarcopenia (i.e., loss of muscle mass and function) commonly observed with aging (Fleg et al. 2017; Springer et al. 2017; Von Haehling et al. 2017). Consequently, the physical function is impaired, affecting the performance in activities of daily living, independence, and quality of life negatively (Fragala et al. 2019). 
MP is an important physical characteristic concerned with an ST program for the elderly, and the power training (PT) is recommended for this purpose (Ratamess et al. 2009). The PT is characterized by strength exercises performed at light to moderate loads (30 - 60\% of 1 Repetition Maximum - RM) at high velocities in explosive movements, mainly in the concentric phase (Ratamess et al. 2009; Fragala et al. 2019). The PT is strongly associated with performance in daily living activities for the elderly. Ramirez-Campillo et al. (2014) compared a 12-week ST program with the exercises performed at high and low-speed. Strength, functional capacity, muscular performance, and quality of life improved in all conditions. These studies reinforces the high-speed protocol improved the MP and functional task performance. Which corroborates the result of the meta-analysis published previously (Tschopp et al. 2011).

The sarcopenia is caused by age and enhanced by HF and CAD which compromises even more the neuromuscular function (Von Haehling et al. 2017; Fragala et al. 2019). A recent NSCA position (Fragala et al. 2019) reinforced that PT increases strength, power, and hypertrophy in the elderly. Therefore, the inclusion of PT seems to be essential and safe for a well-rounded ST program for healthy and cardiovascular disease elderly (Lamotte et al. 2010; Cadore et al. 2018).

Although there is evidence about the benefits of ST in elderly patients with HF and CAD, for muscle power stimulate and, consequently, gains in functional capacity, the higher speed in the concentric phase during ST could be considered in patients undergoing a cardiac rehabilitation program. However, little is known about the assessment of lower limb MP in this population. Thus, the purpose of the present study was to assess and to compare the absolute and relative MP of the lower limbs in the elderly with HF and elderly with CAD, but without HF.

\section{Methodology}

\section{Subjects}

Thirty-six sedentary HF and CAD patients of both sexes participated in this study. They were divided into two groups: a) HF - sixteen patients with HF with an ejection fraction below $50 \%$ in echocardiogram trough Teicholz method (72 \pm 4.3 years, $75 \pm 5.2 \mathrm{~kg}, 171 \pm 9.1 \mathrm{~cm}$ ); and b) CAD - twenty patients with CAD diagnosed through clinical trials and images exams like scintigraphy and cardiac catheterization, but without $\mathrm{HF}(71 \pm 5.2$ years, $75 \pm 5.6 \mathrm{~kg}, 170 \pm 4.8 \mathrm{~cm})$. Before all the procedures, the participants were informed about the risks and benefits of the research and signed the consent form. The study was approved by the Research Ethics Committee of the Faculties of Health Sciences of Juiz de Fora, with an opinion number 847.611.

\section{Experimental Protocol}

Two visits were necessary for the experimental protocol. In the first visit, the participants were submitted on medical evaluation to participate cardiac rehabilitation program. In the second visit, anthropometric and MP assessment were performed. For the anthropometric data, height and body weight were measured with a scale and stadiometer. The MP was evaluated in a half-squat exercise using a linear position transducer (Fitrodyne; Fitronic; Bratislava; Slovakia).

For the MP test, the participants were attached to a belt. The body weight was inserted into the Fitrodyne microcomputer, and then the force in Newtons was calculated (bodyweight $\times 9.81 \mathrm{~m} / \mathrm{s}^{2}$ ). The force was then multiplied by the velocity obtained directly from the linear position transducer during the upward phase of a half squat to obtain the power in Watts. The absolute power was recorded as well as the relative power (absolute power/body weight).

To better discriminate the performance of the exercise, the following stages of execution were established: (1) Initial position - seated, knees flexed $90^{\circ}$ with a small lateral displacement, feet fully supported on the ground with little parallel lateral displacement, arms crossed in front of the thorax and the head positioned with the Frankfurt plane; (2) Concentric phase 
- the complete extension of the lower limbs as fast as possible, keeping the feet resting on the ground; (3) Eccentric phase - the return to the starting position with controlled speed from the end of the concentric phase.

Three repetitions were performed with three seconds of the interval between repetitions. The participants were encouraged to perform the half-squat exercise as fast as possible in the concentric phase. Three attempts were permitted with an interval of 1 minute between them. The highest score obtained was recorded and used for data analysis.

The following strategies were used to minimize error in the test protocol: (1) standardized information about the correct technique was given to the subjects before the test; (2) at least two attempts for familiarization were permitted; (3) a unique experienced professional was responsible for the test; (4) the patient's body weight was measured prior to all tests for the accuracy of the results.

\section{Statistical Analysis}

The sample size was calculated was used the $G^{*}$ Power (v. 3.1.94) and we adopted the following parameters: tails = 2; effect size $=6.50 ; \alpha=0.05$ and, total sample size $\mathrm{HF}=16, \mathrm{CAD}=20$. It was calculated that the sample size was sufficient to provide more than $95 \%$ of statistical power. All the results were described by mean and standard deviation (SD). The parametric assumptions of normality and sphericity were validated by the Shapiro-Wilk test and the Mauchly test, respectively. Unpaired Student's t-tests were used to compare the absolute and relative MP scores between groups. All statistical analyses were performed in Prism software (v.5). Alpha was set at $p \leq 0.05$.

\section{Results and Discussion}

It was shown that the CAD group exhibited significantly higher absolute MP than the HF group (438 $\pm 22.3 \mathrm{~W}$ vs. $362 \pm 18.5 \mathrm{~W} ; p=0.015$ ) (Figure 1$)$.

Figure 1. Analysis of absolute power, for individuals with and without heart failure.

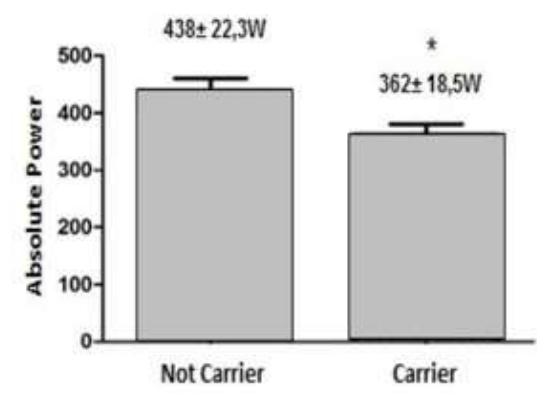

Source: Authors.

Similarly, the relative MP in CAD group was significantly higher than the HF group $(5.9 \pm 0.2 \mathrm{~W} / \mathrm{kg}$ vs. $4.6 \pm 0.2 \mathrm{~W}$ $/ \mathrm{kg}, p=0.001)$ (Figure 2). 
Figure 2. Analysis of relative power, for individuals with and without heart failure.

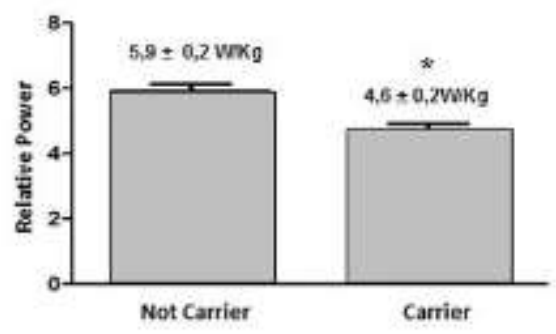

Source: Authors.

\section{Discussion}

In the present study, a higher absolute and relative MP was demonstrated CAD elderly patients compared to HF ones. These results confirmed our hypothesis. The positive association between MP and functional capacity (Barbat - Artigas et al. 2012) demonstrate the poor muscle quality observed in HF elderly patients. Sarcopenia and cachexia are considered 'a muscle disease (muscle failure) rooted in adverse muscle changes that accrue across a lifetime' 4 and plays a main pathophysiological role in frailty in older adults, 5 leading to adverse health outcomes, such as disability, hospital admission, poor quality of life, and mortality (Harrington et al. 1997). As consequence of HF, affecting $20 \%$ and $10 \%$ of the HF ambulatorial patients (Dutt et al. 2015; Von Haehling et al. 2015; Fleg et al. 2017; Von Haehling et al. 2017).. The causes are multifactorial (Von Haehling et al. 2017). Disorders in inflammatory markers as interleukin-6 (IL-6), interleukin-10 (IL-10), and tumor necrosis factor $\alpha$ (TNF- $\alpha$ ) must be considered in HF patients because it impairs the gene expression of muscle proteins (Hambrecht et al. 2002). Neuroendocrine and immunological disorders also influence the sarcopenia in HF patients because it controls the balance between the anabolic and catabolic status of the muscle tissue (Josiak et al. 2014). Several treatment approaches are recommended (Dutt et al. 2015). However, the practice of physical exercises is pointed as an essential non-pharmacological therapy for older HF patients (Fleg et al. 2017).

The practice of physical exercise is mostly recommended for CVD rehabilitation (Price et al. 2016). In HF patients, the main goals of the physical exercise therapy are an increase in $\mathrm{VO}_{2 \text { peak}}$, exercise tolerance and skeletal muscle function, which imply in improvement in the quality of life and daily activities, as walking, climbing stairs, housework and gardening and recreational activities (Selig et al. 2010; Piepoli et al. 2011). According to previous studies, the ST complies with this role. Giuliano et al. (2016) meta-analyzed the effects of the ST as a unique intervention in the strength, endurance, and quality of life in HF patients. They have demonstrated improvement in the strength, $\mathrm{VO}_{2 \text { peak }}, 6$ minutes walking test, and quality of life. The combined training (ST + endurance training) is another recommended approach. In another meta-analysis, Jewiss et al. (2016) quantified if isolated ST or combined training to induce changes in clinical markers in HF patients. The authors

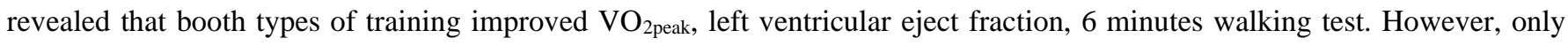
the combined training increased the quality of life and reduced systolic blood pressure and the heart rate at rest.

An ST program may also contribute indirectly to HF elderly patients. According to Conraads et al. (2012), adherence to a physical exercise program for rehabilitation in HF patients is a challenge. Older age, level of disability, difficulty to incorporate exercise into daily life, and lack of time are reasons that compromise the participation. However, an ST program may contribute to this problem. Munch et al. (2018) compared six weeks of low-volume and time-efficient strength and an endurance program. The $\mathrm{VO}_{2 \text { peak, }} 6$ minutes walking test performance, blood flow, endothelial function, and quality of life 
significantly improved in booth programs without significant differences between them. However, the ST program was concluded in $44 \%$ less time and $35 \%$ less energy expended.

The sarcopenic process in HF patients is well described in the literature. However, the assessment of MP in this population was lacking. Therefore, the present study compared the MP in HF patients to CAD ones without HF. It was shown that in the progression of CVD to terminal HF induced a significant difference in muscle function as indicated by MP scores obtained. Future randomized controlled trials manipulating the ST variables (i.e., volume, load, rest interval length, methods, range and speed of motion) is needed. It may evaluate potential associations between HF, muscle dysfunction, specific biochemical markers to establish the functional to pathological connection better.

\section{Conclusion}

In conclusion, patients with HF exhibited significantly less PM in lower limbs compared to patients with CAD without HF, demonstrated by a lower ability to stand, which reflects a lower functional capacity, compromising daily activities and quality of life. It is recommended that patients with HF participate in an ST program to maintain maximum strength and MP levels to increase muscle quality and potentially better treatment outcomes.

\section{References}

Barbat-Artigas, S., Rolland, Y., Zamboni, M., \& Aubertin-Leheudre M. (2012) How to assess functional status: a new muscle quality index. The journal of nutrition, health \& aging. 16(1): 67-77. 10.1007/s12603-012-0004-5

Cadore, E. L, Pinto, R. S, Reischak-Oliveira, Á, \& Izquierdo M. (2018) Explosive type of contractions should not be avoided during resistance training in elderly. Exp. Gerontol. 102: 81-83; 10.1016/j.exger.2017.12.003.

Conraads, V. M., Deaton, C., Piotrowicz, E., Santaularia, N., Tierney, S., Piepoli, M. F., et al. (2012) Adherence of heart failure patients to exercise: barriers and possible solutions: a position statement of the Study Group on Exercise Training in Heart Failure of the Heart Failure Association of the European Society of Cardiology. European journal of heart failure. 14(5): 451-458; 10.1093/eurjhf/hfs048.

Dharmarajan, K., \& Rich, M. W. (2017) Epidemiology, Pathophysiology, and Prognosis of Heart Failure in Older Adults. Heart Failure Clinics. 13(3): 417426; 10.1016/j.hfc.2017.02.001

Drenowatz, C., Sui, X., Fritz, S., Lavie, C. J., Beattie, P. F., Church, T. S., et al. (2015) The association between resistance exercise and cardiovascular disease risk in women. J Sci Med Sport. 18(6): 632-636; 10.1016/j.sams.2014.09.009.

Dutt, V., Gupta, S., Dabur, R., Injeti, E., \& Mittal, A. (2015) Skeletal muscle atrophy: potential therapeutic agents and their mechanisms of action. Pharmacological Research. 99: 86-100; 10.1016/j.phrs.2015.05.010.

European Society of Cardiology. ESC guidelines on the management of stable coronary artery disease. Eur Heart J. 34: 2949-3003. doi.org/10.1093/eurheartj/eht296.

Fleg JL. (2017) Exercise therapy for older heart failure patients. Heart Failure Clinics. 13(3): 607-617; 10.1016/j.hfc.2017.02.012.

Fragala, M. S., Cadore, E. L., Dorgo, S., Izquierdo, M., Kraemer, W. J., Peterson, M. D., et al. (2019) Resistance training for older adults: position statement from the national strength and conditioning association. The Journal of Strength \& Conditioning Research. 33(8): 2019-2052; 10.1519/JSC.0000000000003230.

Giuliano, C., Karahalios, A., Neil, C., Allen, J., \& Levinger, I. (2016) The effects of resistance training on muscle strength, quality of life and aerobic capacity in patients with chronic heart failure - A meta-analysis. Int J Cardiol. 227: 413-423; 10.1016/j.ijcard.2016.11.023.

Hambrecht, R., Schulze, P. C., Gielen, S., Linke, A., Möbius-Winkler, S., Yu, J., et al. (2002) Reduction of insulin-like growth factor-I expression in the skeletal muscle of noncachectic patients with chronic heart failure. Journal of the American College of Cardiology. 39(7): 1175-1181; 10.1016/S07351097(02)01736-9.

Hansen, D., Abreu, A., Doherty, P., \& Völler, H. (2019) Dynamic strength training intensity in cardiovascular rehabilitation: is it time to reconsider clinical practice? A systematic review. European journal of preventive cardiology. 26(14): 1483-1492; $10.1177 / 2047487319847003$.

Harrington, D., Anker, S. D., Chua, T. P., Webb-Peploe, K. M., Ponikowski, P. P., PooleWilson, P. A., \& Coats, A. J. (1997) Skeletal muscle function and its relation to exercise tolerance in chronic heart failure. J Am Coll Cardiol 30:1758-1764; 10.1016/s0735-1097(97)00381-1.

Jewiss, D., Ostman, C., \& Smart, N. A. (2016) The effect of resistance training on clinical outcomes in heart failure: A systematic review and meta-analysis. International Journal of Cardiology. 221: 674-681; 10.1016/j.ijcard.2016.07.046. 
Josiak, K., Jankowska, E. A., Piepoli, M. F., Banasiak, W., \& Ponikowski, P. (2014) Skeletal myopathy in patients with chronic heart failure: significance of anabolic-androgenic hormones. Journal of cachexia, sarcopenia and muscle. 5(4): 287-296; 10.1007/s13539-014-0152-z.

Lamotte, M., Fleury, F., Pirard, M., Jamon, A., \& Borne, P. V. D. (2010) Acute cardiovascular response to resistance training during cardiac rehabilitation: effect of repetition speed and rest periods. European journal of cardiovascular prevention \& rehabilitation. 2010; 17(3): 329-336; 10.1097/HJR.0b013e328332efdd.

Malakar, A. K., Choudhury, D., Halder, B., Paul, P., Uddin, A., \& Chakraborty, S. (2019) A review on coronary artery disease, its risk factors, and therapeutics. Journal of cellular physiology. 234(10): 16812-16823; 10.1002/jcp.28350.

Munch, G. W., Rosenmeier, J. B., Petersen, M., Rinnov, A. R., Iepsen, U. W., Pedersen, B. K., et al. (2018) Comparative Effectiveness of Low-Volume TimeEfficient Resistance Training Versus Endurance Training in Patients With Heart Failure. Journal of cardiopulmonary rehabilitation and prevention. 38(3): $175-181 ; 10.1097 /$ HCR.0000000000000304.

Naghavi, M., Abajobir, A. A., Abbafati, C., Abbas, K. M., Abd-Allah, F., Abera, S. F. et al. (2017) Global, regional, and national age-sex specific mortality for 264 causes of death, 1980-2016: a systematic analysis for the Global Burden of Disease Study 2016. The Lancet. 390(10100), 1151-1210; 10.1016/S0140$6736(17) 32152-9$.

Piepoli, M. F., Conraads, V., Corra, U., Dickstein, K., Francis, D. P., Jaarsma, T., et al. (2011) Exercise training in heart failure: from theory to practice. A consensus document of the Heart Failure Association and the European Association for Cardiovascular Prevention and Rehabilitation. European journal of heart failure. 13(4): 347-357; 10.1093/eurjhf/hfr017.

Price, K. J., Gordon, B. A., Bird, S. R., \& Benson, A. C. (2016) A review of guidelines for cardiac rehabilitation exercise programmes: is there an international consensus? European journal of preventive cardiology. (16): 1715-1733; 10.1177/2047487316657669.

Ramírez-Campillo, R., Castillo, A., Carlos, I., Campos-Jara, C., Andrade, D. C., Álvarez, C., et al. (2014) High-speed resistance training is more effective than low-speed resistance training to increase functional capacity and muscle performance in older women. Experimental gerontology. 58: 51-57. 10.1016/j.exger.2014.07.001.

Ratamess, N., Alvar, B., Evetoch, T., Housh, T., Kibler, W., \& Kraemer, W. (2009) Progression models in resistance training for healthy adults. Med Sci Sports Exerc. 41(3): 687-708. 10.1249/MSS.0b013e3181915670.

Selig, S. E., Levinger, I., Williams, A. D., Smart, N., Holland, D. J., Maiorana, A., et al. (2010) Exercise \& Sports Science Australia Position Statement on exercise training and chronic heart failure. Journal of Science and Medicine in Sport. 13(3): 288-294; 10.1016/j.jsams.2010.01.004.

Singh, M. A. F. (2019) Tailoring Assessments and Prescription in Cardiac Rehabilitation for Older Adults. Cardiac Rehabilitation, An Issue of Clinics in Geriatric Medicine. 35(4): 423-443; 10.1016/j.cger.2019.07.013

Shiroma, E. J, Cook, N R, Manson, J. E, Moorthy, M. V., Buring, J. E, Rimm, E. B, et al. (2017) Strength training and the risk of type 2 diabetes and cardiovascular disease. Medicine and science in sports and exercise. 49(1): 40; 10.1249/MSS.0000000000001063.

Springer, J., Springer, J. I., \& Anker, S. D. (2011) Muscle wasting and sarcopenia in heart failure and beyond: update. ESC Heart Failure. 4(4): 492-498; 10.1002/ehf2.12237.

Tschopp, M., Sattelmayer, M. K., \& Hilfiker, R. (2011) Is power training or conventional resistance training better for function in elderly persons? A metaanalysis. Age and Ageing. 40(5): 549-556; 10.1093/ageing/afr005.

Von Haehling, S. The wasting continuum in heart failure: From sarcopenia to cachexia. Proceedings of the Nutrition Society. 74(4): 367-377; $10.1017 /$ S0029665115002438.

Von Haehling, S., Ebner, N., Dos Santos, M. R., Springer, J., \& Anker, S. D. (2017) Muscle wasting and cachexia in heart failure: mechanisms and therapies. Nature Reviews Cardiology. 14(6): 323; 10.1038/nrcardio.2017.51.

Xanthos, P. D., Gordon, B., \& Kingsley, M. I. C. (2017) Implementing resistance training in the rehabilitation of coronary heart disease: A systematic review and meta-analysis. International Journal of Cardiology. 230: 493-508; 10.1016/j.ijcard.2016.12.076.

Yancy, C. W., Jessup, M., Bozkurt, B., Butler, J., Casey, D. E., Drazner, M. H., et al. (2013) ACCF/AHA guideline for the management of heart failure: a report of the American College of Cardiology Foundation/American Heart Association Task Force on Practice Guidelines. Journal of the American College of Cardiology. 62(16): e147-e239; 10.1016/j.jacc.2013.05.019. 